\title{
WASTE MANAGEMENT SERVICE IN INDONESIA BASED ON STOCHASTIC FRONTIER ANALYSIS
}

\author{
Nurul Laily Luthfiani ${ }^{1}$, Hastarini Dwi Atmanti ${ }^{2}$ \\ 1nurullaily96@gmail.com \\ Diponegoro University \\ Jl. Prof. Sudarto No.13, Tembalang, Semarang, Jawa Tengah 50275
}

received: 24/4/21; revised: 31/7/21; approved: 20/12/21

\begin{abstract}
Waste management in the big cities of Indonesia is still become a complicated problem. This article aims to analyze the influence of socio-economic factors which consist of GRDP per capita, population density, gender ratio, the proportion of population productive age and education on the efficiency of waste management service (WMS) in provincial capitals in Indonesia. The method used was Stochastic Frontier Analysis (SFA). The resulted WMS efficiency from this study were 0.39. Based on that value, it means the efficiency of WMS are still low and the efficiency can be improved about $61 \%$. It also can be concluded that all variables were significantly influenced the WMS efficiency, except gender ratio. Expected that the result of this study can be used by both central and local government to improve the WMS in Indonesia.
\end{abstract}

Keywords:efficiency; municipal solid waste; waste management service; stochastic frontier analysis

\section{INTRODUCTION}

Waste can be serious problem in the country because unmanaged accumulation of waste will cause soil, water, and air pollution. This condition will increase the possibility of health problems and disease transmission to the community (Opara, et al., 2016). Many factors affect waste production in the certain area, such as demographics condition, economic growth, as well as the population (Guerrini, et al., 2017). Indonesia as a development country with the fourth highest population in the world (268.08 million), (Badan Pusat Statistik Republik Indonesia, 2020) also cannot avoid this problem.

Indonesia waste management is still based on conventional method, the centralized collection method. It was stated on ministry PU/PR regulation No.3/PRTM/2013 that waste management methods implemented by the government are sorting, collecting, transporting, processing and final processing. The final waste processing, commonly in big cities of Indonesia, is carried out by sanitary landfill system. The accumulation of waste is piled with soil in landfills, known as Tempat Pembuangan Akhir (TPA). However, this method is not considered the best method, because the collection, processing and disposal of waste is currently still inadequate. It has been estimated that $40 \%$ of the waste produced by big cities in Indonesia is not transported to the landfill (Damanhuri and Padmi, 2010). The landfill has no longer to accommodate all of the municipal solid waste. The problem of waste management in many cities of the developing countries is insufficient collection of solid waste and the poor quality of the waste transportation.

Big cities and provincial capitals contribute most of the amount of waste in Indonesia. Currently, Indonesia's population lives in cities generated 105,000 tons per day and is predicted will increase to 150,000 tons per day by 2025 (World Bank, 2019). The increase in population, economic activities as well as urbanization cause the amount of waste in this area tends to be greater than that of other cities or regencies around it.

The Indonesian Government through Presidential Regulation No. 97/2017 has targeted 100\% of waste must be managed by 2025 . This can be achieved by a $30 \%$ reduction in waste and $70 \%$ waste handling or services. Success indicators of waste management can be proven from the large increase in sorting, collection, transportation, processing, and final processing of the waste. To achieve this target, a strategy is needed so that the waste can be transported and processed by the government. This research will give contribution especially for the government in taking policy to achieve the target of waste management by implementing an efficient and appropriate service pattern. Waste management efficiency is one of the strategies to improve management efforts by optimizing the limited budget and resources. Efficiency of waste management together with the use of social and economic factors will increase the landfill age and will have a major impact on achieving zero waste targets in Indonesia. 
Various factors can influence waste management with social and economic conditions are the most influential factors (Simões, et al., 2010; Simões and Marques, 2011; Al-Khatib, et al., 2015; Babaei, et al., 2015; Zaman, 2016; Atmanti, et al., 2019; Fan, et al., 2020). In addition, education also become significant effect because higher education level will increase knowledge and concern for the environment (Putra, et al., 2013; Cynk, 2017). GRDP, which symbolizes the economic level of a region, also can increase the management because waste collection services and facilities can be better financially managed (Simões, et al., 2010). People in productive age (15-64) which have more knowledge of the environment and they are active in environmental activities or communities (Al-Khatib, et al., 2015; Fan, et al., 2020), the population density of an area also significant factors. The higher the population density in an area, the more difficult waste will be transported and collected (Vishwakarma, et al., 2012).

Waste management assessment can be realized through an analysis of the value of efficiency and inefficiency. The efficiency of waste management service (WMS) is a way to assess the performance of the government in providing solid waste services to the community (Atmanti, et al., 2019). Some methods are available to analyze the efficiency based on parametric and non-parametric method. In the context of multi-input and single-output production, parametric methods such as stochastic frontier analysis (SFA) make assumptions about the functional relationship between input and output variables and are suitable for analyzing the efficiency of multiple inputs and one case of output. In this study, waste collection as WMS is single output while collection tools, transport equipment and labor are inputs. The functional ralationship between input and output variables are suitable for analyzing the efficiency of multiple inputs (GRDP per capita, population density, gender ratio, the proportion of population productive age and education). Other great strength and advantage of using SFA compared to nonparametric method is the SFA consider the effect of random factors on the output and this increases the accuracy of the estimation process (Mutz, et al., 2017). The SFA method is designed to reduce the effect of fluctuations or random variables. Moreover, the efficiency values and regression parameters in the production system can be estimated in an unbiased way (Wang and Schmidt, 2002). It is simpler and better than the twostage method of nonparametric estimation, because second stage Ordinary Least Square (OLS) estimation in nonparametric methods such as Data Envelopment Analysis (DEA) is often inconsistent with the actual data generation process (Simar and Wilson, 2011).

Research on the efficiency of waste management using SFA has been conducted by Fan, et al. (2020) and Atmanti, et al., (2019) using input from various kinds of waste facilities including waste collection tools, transportation equipment and labors. Atmanti, et al., (2019) research was conducted in Central Java Province using dummy areas (cities/districts) and education as factors that affect efficiency. In this study, the analysis of waste management did not involve social and economic variables as factor variables that affect the efficiency of waste management in provincial capitals in Indonesia. While (Fan, et al, 2019) did the study in China which have different in geographical and demography conditions with Indonesia that effects on equalization of waste collection service and waste management policy.

Therefore, this article aims to analyze the effect of economic factors in the form of GRDP per capita and various other social factors such as population density, gender ratio, the proportion of productive age population and education on the efficiency of WMS in Indonesia using the SFA method. So that local governments can regulate social and economic policies to improve the efficiency of waste management services in each region.

\section{METHODS}

Indonesia consists of 34 provinces, each of them has a provincial capital as the center of economic growth. This study analyzed waste management in 29 out of 34 capital cities in Indonesia. 5 cities (Pekanbaru, Yogyakarta, Manado, Manokwari and Jayapura) were not included in the analysis due to data limitations. The data were obtained from the Badan Pusat Statistik (BPS) Indonesia and Dinas Lingkungan Hidup (the environmental services) in the relevant regions.

This study calculated the technical value of efficiency using the Stochastic Frontier Analysis (SFA) method. According to Aigner, et al. (1997) in (Coelli, et al., 1998), The stochastic frontier function is a production function where the output in the study is limited by the stochastic (random effect). The analysis tool used was the Frontier 4.1 software. The stochastic frontier production function is:

$$
\ln \left(Y_{i t}\right)=X_{i t} \beta+\left(v_{i t}-u_{i t}\right) \ldots
$$

Where $\mathrm{i}=1,2, \ldots . \mathrm{N}$. Yi is waste transported in the cities in year $\mathrm{t} ; \mathrm{X}_{\mathrm{it}}$ is the input or input atau factors affecting the frontier output at time $t ; \beta$ is the calculated coefficient parameter; $\left(v_{i t}-u_{i t}\right)$ is the error; $v_{i t}$ is random variable assumed to be independently identically distributed (i.i.d) $\mathrm{N}\left(0, \sigma^{2} v\right)$ and independent from $\mathrm{u}_{\mathrm{it}}$; $\mathrm{u}_{\mathrm{it}}$ is non-negative random variable that describe technical inefficiencies in the production function. 
The calculation of technical inefficiency in research was developed by Coelli et al. in 1995. The $\mathrm{u}_{\mathrm{i}}$ variable is an effect of technical inefficiency which is assumed to be independent and half-normal distributed with

$$
\mathrm{m}_{\mathrm{it}}=\mathrm{z}_{\mathrm{it}} \delta
$$

$\mathrm{m}_{\mathrm{it}}$ is the average of the inefficiency function of transported waste in i cities at time $\mathrm{t} ; z_{\mathrm{it}}$ is a factor affecting inefficiency in $i$ cities at time $t$; and $\delta$ is the calculated inefficiency factor parameter. Because 5 factors were considered so (2) is then adjusted to be:

$$
\begin{aligned}
& \mathrm{m}_{\mathrm{it}}=\delta_{0}+\delta_{1} Z_{1 \mathrm{it}}+\delta_{2} \mathrm{Z}_{2 \mathrm{it}}+\delta_{3} \mathrm{Z}_{3 \mathrm{it}}+\delta_{4} \mathrm{Z}_{4 \mathrm{it}}+\delta_{5} \mathrm{Z}_{5 \mathrm{it}} \\
& \mathrm{m}_{\mathrm{it}}=\delta_{0}+\sum_{\mathrm{k}=1}^{5} \delta_{\mathrm{k}} Z_{\mathrm{kit}}
\end{aligned}
$$

$\delta_{0}, \delta_{1}, \delta_{2}, \delta_{3}, \delta_{4}, \delta_{5}$ are the calculated inefficiency factor parameter which consist of constant parameter, GRDP per capita, population density, gender ratio (male/female ratio), proportion of productive aged population, and average length of schooling, respectively; $Z_{1 i t}, Z_{2 i t}, Z_{3 i t}, Z_{4 i t}, Z_{5 i t}$ is a factor affecting inefficiency for each $\delta$.

Technical efficiency analysis can be measured using equation (4):

$$
\mathrm{TE}_{\mathrm{it}}=\frac{\mathrm{y}_{\mathrm{i}}}{\exp \left(\mathrm{x}_{\mathrm{i}} \beta\right)}=\frac{\exp \left(\mathrm{x}_{\mathrm{i}} \beta-\mathrm{u}_{\mathrm{i}}\right)}{\exp \left(\mathrm{x}_{\mathrm{i}} \beta\right)}=\exp \left(-\mathrm{u}_{\mathrm{i}}\right)
$$

$\mathrm{TE}_{\mathrm{it}}$ is technical efficiency in waste management in $\mathrm{i}$ cities in year $\mathrm{t}$. If $\mathrm{u}_{\mathrm{it}}>0$, and $0<\mathrm{TE}_{\mathrm{it}}<1$, it means that there are technical inefficiencies in waste management in Indonesia. Meanwhile, if $u_{i t}=0$ and $\mathrm{TE}_{\mathrm{it}}=1$ it means there are no technical inefficiencies in waste management in Indonesia.

The frontier production function and technical inefficiency can be calculated through the maximum likelihood. SFA can be tested using $\gamma$ whose values range from 0 to 1. According to Battase and Corra (1977), in Coelli et al (1998) the estimated of variance parameters are:

$$
\begin{gathered}
\gamma=\frac{\sigma^{2}}{\sigma_{\mathrm{s}}} \\
\sigma_{\mathrm{s}}{ }^{2}=\sigma_{\mathrm{v}}{ }^{2}+\sigma^{2}
\end{gathered}
$$

$\sigma_{\mathrm{s}}{ }^{2}$ is total variance of error term, and $\gamma$ is parameter to see the contribution of technical efficiency to the overall residual effect. While $\gamma$ is closer to zero, it means the random variation in observed output is explained by the influence of random or variable stochastic outside the study. Otherwise, if $\gamma$ is closer to one, it means the random variation in observed output is explained by the influence of inefficiencies contained in the research model. The selection of equations is based on the generalized likelihood-ration (LR-test) that is:

$$
\begin{aligned}
& \mathrm{LR}=-2\left\{\ln \left[\mathrm{L}\left(\mathrm{H}_{0}\right) / \mathrm{L}\left(\mathrm{H}_{1}\right)\right]\right\} \\
& \mathrm{LR}=-2\left\{1 \mathrm{n}\left[\mathrm{L}\left(\mathrm{H}_{0}\right)\right]-\ln \left[\mathrm{L}\left(\mathrm{H}_{1}\right)\right]\right\}
\end{aligned}
$$

Where $\mathrm{L}\left(\mathrm{H}_{0}\right)$ and $\mathrm{L}\left(\mathrm{H}_{1}\right)$ are the value of the likelihood function of the null hypothesis and the alternative hypothesis, respectively. $\mathrm{L}\left(\mathrm{H}_{0}\right)$ is the likelihood value of the restricted frontier model, while $\mathrm{L}\left(\mathrm{H}_{1}\right)$ is the likelihood value of the translog frontier equation. If the $L R$ test value is greater than the critical value of the chi-square table $\left(\chi^{2}\right)$ delimited by degree of freedom (df), then $\mathrm{H}_{0}$ is rejected and the translog frontier equation $\left(\mathrm{H}_{1}\right)$ is accepted.

Null hypotheses of $\beta_{\mathrm{nt}}=0$ used for testing alternative hypotheses with the Hicks-Neutral equation, null hypotheses of $\beta_{\mathrm{t}}=\beta_{\mathrm{tt}}=\beta_{\mathrm{nt}}=0$ for testing with the equation of No-Technological Progress, null hypotheses of $\beta_{\mathrm{tt}}=\beta_{\mathrm{nt}}=\beta_{\mathrm{nk}}=0$ for testing with the Cobb Douglas equation, and null hypotheses of $\gamma=\delta_{0}=\delta_{\mathrm{j}}=0$ for testing alternative hypotheses with the no-inefficiency effect equation. In the effects of inefficiencies testing of the production function, the critical value of the chi-square table $\left(\chi^{2}\right)$ used critical values from the table (Kodde and Palm, 1986) which will then be called "mixed chi-square".

The output variables are the amount of transported waste collected at the TPA, and the input variables are labors, garbage trucks, temporary dumps (TPS) and large transportation equipment (street sweepers, tipper trucks and others). Based on (1), this study used production function of Hicks Neutral:

$$
\ln \left(\mathrm{Y}_{\mathrm{it}}\right)=\ln \beta_{0 \mathrm{i}}+\sum_{\mathrm{n}=1}^{\mathrm{N}} \beta_{\mathrm{n}} \ln \mathrm{X}_{\mathrm{nit}}+1 / 2 \sum_{\mathrm{n}=1}^{\mathrm{N}} \sum_{\mathrm{k}=1}^{\mathrm{N}} \beta_{\mathrm{nk}} \ln \mathrm{X}_{\mathrm{kit}}+\beta_{\mathrm{t}} \mathrm{t}+1 / 2 \beta_{\mathrm{it}} \mathrm{t}^{2}+\left(\mathrm{v}_{\mathrm{i}}-\mathrm{u}_{\mathrm{i}}\right) \ldots
$$




\section{RESULTS}

Table 1. Descriptive Statistic

\begin{tabular}{lccccc}
\hline \multicolumn{1}{c}{ Variable } & Observation Number & Mean & Std. Deviation & Min & Max \\
\hline Transported waste (tons) & 145 & 663.265 & 1250.54 & 16.1 & 7702.07 \\
Labors/L (person) & 145 & 1259.648 & 2331.066 & 41 & 13730 \\
Garbage truck/TRUCK (unit) & 145 & 119.510 & 322.052 & 3 & 2062 \\
Temporary waste storage/TWS (unit) & 145 & 233.503 & 285.122 & 5 & 1486 \\
Heavy equipment/ HE (unit) & 145 & 162.510 & 370.552 & 4 & 2365 \\
GRDP per capita/ GRDP (million rupiah/person) & 145 & 50.384 & 30.152 & 19.94 & 174.14 \\
Population density/PDS (person/km2) & 145 & 4315.02 & 4022.58 & 10.05 & 15900 \\
Gender Ratio/ GR (specific value) & 145 & 101.717 & 3.657 & 90 & 115 \\
Proportion of population aged 15-64/ AGE (percen) & 145 & 70.271 & 1.943 & 64.26 & 73.52 \\
Education/EDU (years) & 145 & 10.552 & 1.071 & 6.94 & 12.64 \\
\hline
\end{tabular}

Table 1 shows the descriptive statistical results of the data used in the calculation of the production function. The average waste transported is 663.26 tons with a larger standard deviation value. This result shows the uneven distribution of transported waste in provincial capitals in Indonesia. It means, some areas have good waste transportation, but other areas this still poorly transported. This might be happened because quality and quantity of waste facilities and infrastructure owned by each region could be different (Atmanti, et al., 2019). This is also reinforced by the average value of the input variables i.e., labor, trucks, landfills, and large equipment are less than the standard deviation. It means, the input quantity is not evenly distributed in each region.

Various models have been calculated to select the model that best describes the production function. Various research models will be compared with the translog model as the basic model. The log-likelihood value of each model will be processed to obtain the generalized log-likelihood ratio, $\lambda$. Then the generalized log-likelihood ratio will be compared with the distribution value $\chi^{2}$. The production function model chosen is the hicks-neutral model and there is an inefficiency effect in the model. The detailed model selection process is described in Table 2.

Table 2. Test of Hypothesis

\begin{tabular}{lccccc}
\hline \multicolumn{1}{c}{ Test } & $\mathrm{H}_{0}$ & $\mathrm{df}$ & $\lambda$ & $\chi^{2} 1 \%$ & Conclusion \\
\hline Hicks neutral & $\beta_{\mathrm{nt}}=0$ & 4 & -8.46 & 13.27 & Hicks neutral accepted \\
No technological progress & $\beta_{\mathrm{t}}=\beta_{\mathrm{tt}}=\beta_{\mathrm{nt}}=0$ & 6 & 12.22 & 16.81 & No technological progress accepted \\
Cobb douglas & $\beta_{\mathrm{nk}}=\beta_{\mathrm{t}}=\beta_{\mathrm{tt}}=\beta_{\mathrm{nt}} 0$ & 16 & 65.53 & 31.99 & Cobb douglas rejected \\
No inefficiency & $\gamma=\delta_{0}=\delta_{\mathrm{j}}=0$ & 16 & 175.84 & $31.35^{*}$ & No inefficiency rejected \\
\hline
\end{tabular}

Ternate
Ambon
Mamuju
Gorontalo
Kendari
Makasar
Palu
Tanjung Selor
Samarinda
Banjarmasin
Palangkaraya
Pontianak
Kupang
Mataram
Denpasar
Serang
Surabaya
Semarang
Bandung
DKI Jakarta
Tanjung Pinang
Pangkai Pinang
Bandar Lampung
Bengkulu
Palembang
Jambi
Padang
Medan
Banda Aceh

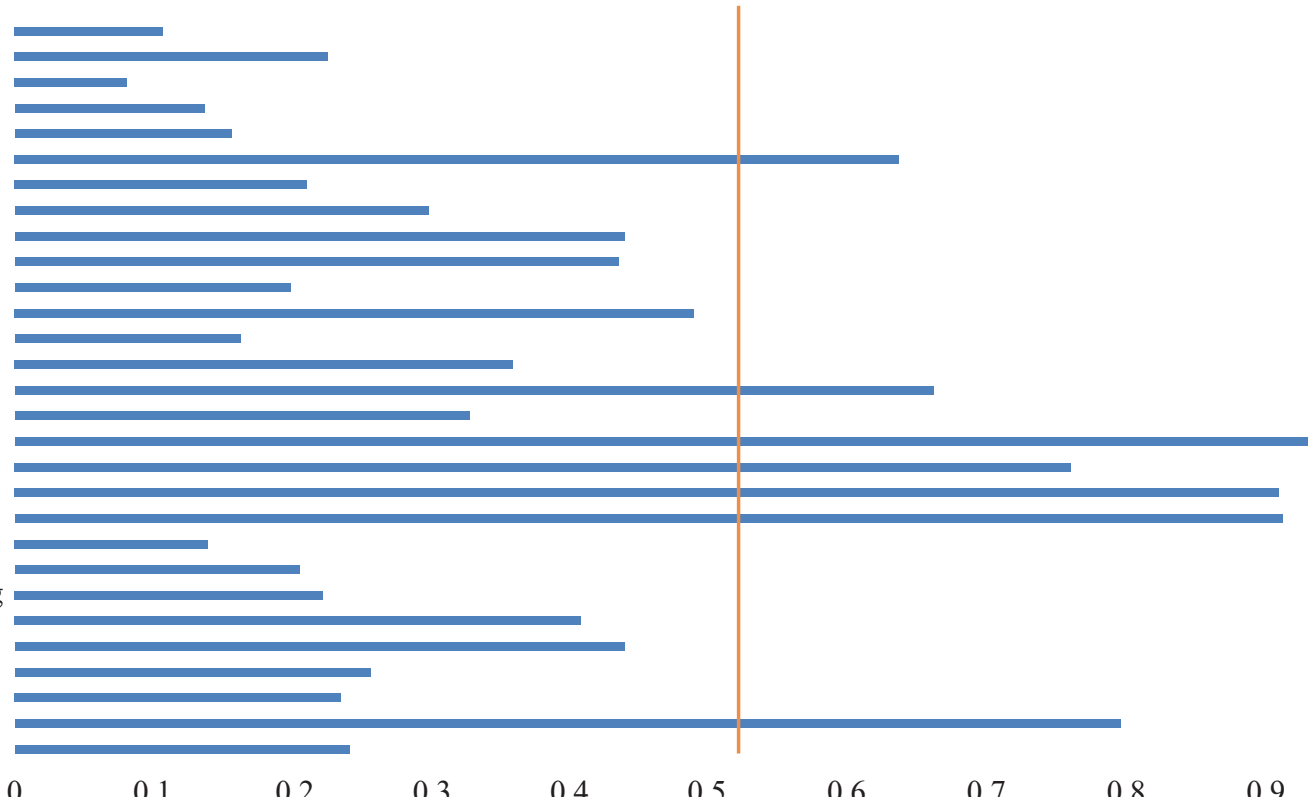

Figure 1. Average efficiency of waste management service in Indonesia 2015-2019 
The calculation using Frontier 4.1 shows that the average result of waste management efficiency in Indonesia was 0.39 . It means the efficiency of WMS are still low and the efficiency can be improved about $61 \%$. Figure 1 shows that among the 29 cities, 12 cities have an average waste management efficiency above the average waste management in Indonesia, while the others are still below the average.

Regional differences significantly affect the index value of environmental ignorance (Badan Pusat Statistik, 2018). In addition, the western region of Indonesia, especially the provincial capital on the Java Island, has a higher waste management efficiency than other regions and is above the average efficiency of Indonesian waste management. These cities are Surabaya, DKI Jakarta, Bandung dan Semarang which are located on Java Island the center of government. So that the waste management system gets more attention compared to other cities.

The highest efficiency of waste management is in Surabaya. In 2017, Surabaya was recognized internationally as the best city in the world in the "Global Green City" category and received appreciation for its reforestation and waste reduction programs. (Andina, Gatot and Senayan, 2019).

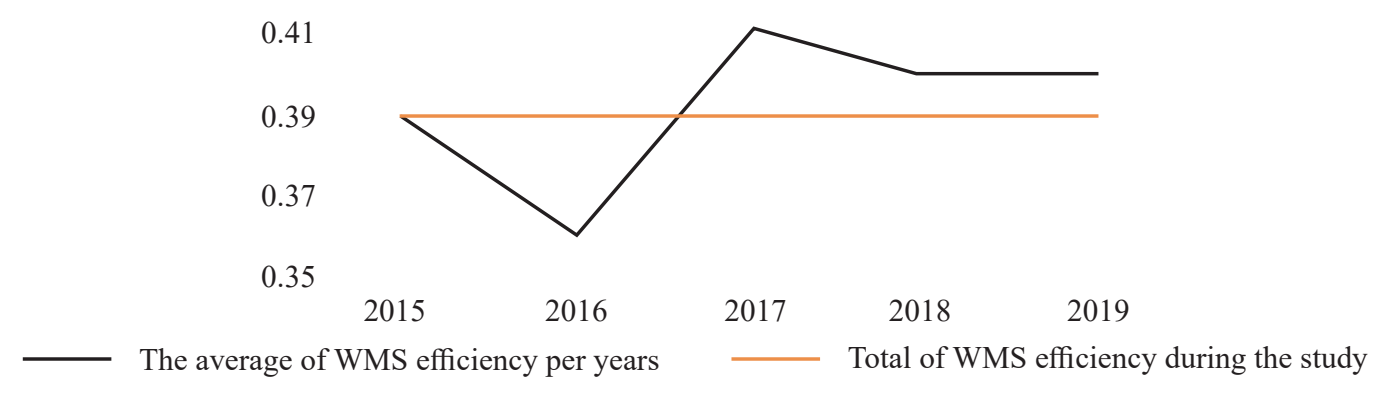

Figure 2. The efficiency distribution of waste management service

Figure 2 shows that in 2017 a large increase in the efficiency of waste management in Indonesia was occurred. This year the government issued PERPRES No 97/2017 about the National Policy and Strategy (Jaktranas) for the Management of Household Waste and Waste Similar to Household Waste. The Indonesian government has targeted $100 \%$ of waste management to be properly managed by 2025 . This target was measured by reducing waste by $30 \%$, and handling waste by $70 \%$.

The central government was revitalizing the Adipura program, financial, and technology assistance to encourage waste management in local governments. In addition, the local government has issued a policy of limiting single-use plastic waste. This step was expected to change the behavior of the community so that can reduce the generated single-used plastic waste (Kementerian Lingkungan Hidup dan Kehutanan, 2020).

\section{DISCUSSIONS}

Based on Table 1, the biggest influence of inefficiency is on education and the smallest effect is population density. All variables have a significant influence on the efficiency of waste management in Indonesia, except gender ratio. The GRDP per capita coefficient is -0.0140 and is significant at $\alpha 1 \%$. GRDP per capita is negatively related to inefficiency. In other words, GRDP per capita is positively related to the efficiency of waste management. In contrast to the research results of (Fan, et al., 2020) GRDP per capita has a negative effect on the efficiency of waste management. However, this result was consistent with the study of Simões, et al., (2010) and Zaman (2016) showing that the high GRDP per capita will increase investment and economic incentive policies in the waste management system that are very much needed in increasing efficiency and recycling of waste. Based on the ignorance index of waste management (IIWM) for provinces in Indonesia, regions that have high GDPR per capita have low IIWM scores (Badan Pusat Statistik, 2018).

The population density coefficient is -0.0001 and is significant at $\alpha 1 \%$. Population density is negatively related to inefficiency or in other words, positively related to the efficiency of waste management. This result differs from the prediction that efficiency in waste management will be difficult to achieve in populous areas. Population density will occur in the city center. The farther area from the city centers the population density tends to be low. This condition causes waste management to tend to be inefficient in rural areas which have a low population density. So that, the condition makes it difficult for the government to provide and maintain waste facilities and it requires greater costs for each transportation process (Passarini, et al., 2011). Although the city center tend to be populous, the infrastructure such as roads are in better condition than the periphery areas, so that the process of waste collecting is easier. Because of this closeness, controlling the quantity and quality of waste equipment, and human resources become easier as well which can improve the efficiency of 
waste management (Abarca, et al., 2013).

Gender ratio is negatively related to efficiency, but not significant. The more male population, the lower the level of efficiency. The presence of women in the house can reduce until $90 \%$ the amount of household waste that must be collected by the government, so that the efficiency of waste management is greater (Kala, et al., 2020). The role of women in waste management is very important, a housewife can share their knowledge about waste management with their children so that the waste that is managed in the upstream sector can get bigger (Popli, et al., 2017). However, the number of occupants of the house could be more important than the effect of gender in waste recycling and housewife is not defined as a women only, but it is defined as everyone who does domestic work for their family unpaid (Rybova, 2019).

The proportion of the population aged 15-64 years is negatively associated with inefficiency and is significant at $\alpha 1 \%$. This shows that the population of productive age has a positive influence on the efficiency of waste management. People at this age have high attitudes and good habits in recycle activities that can reduce the amount of generated waste (Babaei, et al., 2015). Moreover, students (aged 18-24 years) tend to have freedom in activities including environmental activities (reduce, reuse, recycle) or be active in the environmental community (Al-Khatib, et al., 2015; Fan, et al., 2020).

Education is positively related to inefficiency and is significant at $\alpha 5 \%$. This shows that education is negatively related to the efficiency of waste management. The results showed that higher education would make waste management efficiency difficult to achieve. This is different from the estimation that the higher the education, the higher the efficiency. Wang, et al., 2020 said that education only increases individual knowledge of waste management, but the level of participation and the habit of recycling waste for individual is still low. Education about the environment and waste recycling practices is still very low in Indonesia. This causes a lack of responsibility in managing waste in the upstream sector and makes people rely solely on the government to deal with solid waste problems. The negative relationship between education and the efficiency of waste management in Indonesia can also occur because the level of education in Indonesia is still low, in the level of junior high school in average. The low level of education can create a negative relationship between waste management and education (Atmanti, et al., 2019).

\section{CONCLUSIONS}

The efficiency of waste management in Indonesia is still not good with an average efficiency of 0.39. Only $41 \%$ of provincial capitals have an average WMS efficiency above the average WMS efficiency in Indonesia. Economic and social variable factors that are GRDP per capita, population density, proportion of population age 15-64 and education, except gender ratio, have a significant influence on the efficiency of WMS. Gender ratio do not signifanctly affect WMS efficiency because housewives are defined as a women only, instead everyone who does domestic work for their family unpaid. Moreover, the number of occupants of the house may be more important than the effect of gender in waste recycling.

Education has the greatest influence on efficiency and has a negative relationship. This means that the higher a person's education level, the lower the efficiency of waste management will be. The government takes a big role in determining education policies to increase efficiency. Education will increase knowledge about the environment, but awareness, willingness, and behavior in protecting the environment is still low. Waste is only disposed of and managed by the government without reduce, reuse, and recycle behavior in the community.

The optimal waste management can be accomplished if the government, the community, and various stakeholders are involved in this process. The government as a policy maker must make strong rules regarding waste management by households and industries. Awareness of waste problems and responsibility to manage the waste independently also needs to be strengthened by the community and stakeholders. If the government and all levels of society participate in waste management, the target of zero waste in 2025 is optimistically can be realized.

City governments tend to be more concerned with waste management services than district and rural areas. This needs to be maintained by strengthening the budget for waste management and maximizing solid waste services. Waste facilities and infrastructure managed by the government also need to be maintained and updated and can be adapted to the transportation area.

Waste bank also play a big role in waste management. many people of productive age who participate in the waste bank. The Indonesian Ministry of Environment stated that the waste bank had contributed to managing waste by $1.7 \%$ of the total waste in Indonesia in 2018 . Government support for the waste bank program, whether funding or distributing recycled goods, is very important to mobilize the community to reduce the amount of waste and motivate other communities to carry out similar movements. 


\section{REFERENCES}

Abarca, L., Maas, G. and Hogland, W. 2013. Solid Waste Management Challenges for Cities in Developing Countries. Waste Management. Elsevier Ltd, 33(1), pp. 220-232. doi: 10.1016/j.wasman.2012.09.008.

Al-Khatib, I.A., Kontogianni, S., Nabaa, H.A. and Al-Sari, M.I., 2015. Public Perception of Hazardousness Caused by Current Trends of Municipal Solid Waste Management. Waste Management, 36, pp.323-330. doi: 10.1016/j.wasman.2014.10.026.

Andina, E., Gatot, J. and Senayan, S. 2019. Analisis Perilaku Pemilahan Sampah di Kota Surabaya. 10(2).

Atmanti, D. H., Handoyo, R. D. and Muryani. 2019. Efficiency of Waste Management in Indonesia (Case Study in Central Java province), Eco. Env. \& Cons, 25(3).

Atmanti, H. D., Sasana, H. and Setyaningsih, Y. 2019. Waste Management Efficiency In Semarang. International Journal of Civil Engineering and Technology (IJCIET), 10(03), pp. 2440-2448.

Babaei, A.A., Alavi, N., Goudarzi, G., Teymouri, P., Ahmadi, K. and Rafiee, M., 2015. Household Recycling Knowledge, Attitudes and Practices Towards Solid Waste Management. Resources, Conservation and Recycling, 102, pp.94-100. doi: 10.1016/j.resconrec.2015.06.014.

Badan Pusat Statistik. 2018. Laporan Indeks Perilaku Ketidakpedulian Lingkungan Hidup Indonesia. p. 44. doi: 978-602-432-210-0.

Badan Pusat Statistik Republik Indonesia. 2020. Statistik Indonesia.

Coelli, T., Rao, D. S. P. and Battese, G. E. 1998. An Introduction to Efficiency and Productivity Analysis. Kluwer Academy Publisher.

Cynk, K. 2017. The State of The Environmental Awareness of Students from Poland. Slovakia And UkraineSelected Results, 24(1), pp. 21-37. doi: 10.1515/ceer-2017-0002.

Damanhuri, E. and Padmi, T. 2010. Diktat Kuliah TL-3104 Tentang Pengelolaan Sampah.

Fan, X., Yu, B., Chu, Z., Chu, X., Huang, W.C. and Zhang, L., 2020. A Stochastic Frontier Analysis of the efficiency of municipal solid waste collection services in China. Science of The Total Environment, 743, p.140707. doi: 10.1016/j.scitotenv.2020.140707.

Guerrini, A., Carvalho, P., Romano, G., Marques, R.C. and Leardini, C., 2017. Assessing Efficiency Drivers in Municipal Solid Waste Collection Services through a non-Parametric Method. Journal of Cleaner Production, 147, pp.431-441. doi: 10.1016/j.jclepro.2017.01.079.

Kala, K., Bolia, N. B. and Sushil. 2020. Effects of Socio-economic Factors on Quantity and Type of Municipal Solid Waste. 31(4), pp. 877-894. doi: 10.1108/MEQ-11-2019-0244.

Kementerian Lingkungan Hidup dan Kehutanan. 2020. KLHK: Indonesia Memasuki Era Baru Pengelolaan Sampah. Available at: http://ppid.menlhk.go.id/siaran_pers/browse/2329 (Accessed: 18 March 2021).

Mutz, R., Bornmann, L. and Daniel, H. D. 2017. Are There Any Frontiers of Research Performance? Efficiency Measurement of Funded Research Projects with the Bayesian Stochastic Frontier Analysis for Count Data. Journal of Informetrics. Elsevier Ltd, 11(3), pp. 613-628. doi: 10.1016/j.joi.2017.04.009.

Opara, J. A., John, A. K. and Sempewo, J. 2016. Environmental Health Efficiency and Urbanization: The Case Solid Waste Management in Bor Municipality of South Sudan. International Journal of Bioinformatics and Biological Science, 4(1), p. 19. doi: 10.5958/2321-7111.2016.00004.4.

Passarini, F., Vassura, I., Monti, F., Morselli, L. and Villani, B., 2011. Indicators of Waste Management Efficiency Related to Different Territorial Conditions. Waste management, 31(4), pp.785-792. doi: 10.1016/j. wasman.2010.11.021.

Popli, K., Sudibya, G. L. and Kim, S. 2017. A Review of Solid Waste Management using System Dynamics Modeling A Review of Solid Waste Management using System Dynamics Modeling. (October). doi: 10.5322/ JESI.2017.26.10.1185.

Putra, H. P., Taufiq, A. R. and Juliani, A. 2013. Studi Hubungan antara Tingkat Pendidikan dan Pendapatan Keluarga terhadap Sikap dalam Pengelolaan Sampah Rumah Tangga', 5, pp. 91-101.

Rybova, K. 2019. Do Sociodemographic Characteristics in Waste Management Matter? Case Study of Recyclable Generation in the Czech Republic. Sustainability (Switzerland), 11(7). doi: 10.3390/su11072030.

Simar, L. and Wilson, P. W. 2011. Two-stage DEA: Caveat emptor. Journal of Productivity Analysis, 36(2), pp. 205-218. doi: 10.1007/s11123-011-0230-6.

Simões, P. and Marques, R. C. 2011. How Does the Operational Environment Affect Utility Performance? A Parametric Study on the Waste Sector. Resources, Conservation and Recycling, 55(7), pp. 695-702. doi: 10.1016/j.resconrec.2011.02.001.

Simões, P., De Witte, K. and Marques, R. C. 2010. Regulatory Structures and Operational Environment in the Portuguese Waste Sector. Waste Management. Elsevier Ltd, 30(6), pp. 1130-1137. doi: 10.1016/j. wasman.2009.12.015. 
Vishwakarma, A., Kulshrestha, M. and Kulshreshtha, M. 2012. Efficiency Evaluation of Municipal Solid Waste Management Utilities in the Urban Cities of the State of Madhya Pradesh, India, Using Stochastic Frontier Analysis. Benchmarking, 19(3), pp. 340-357. doi: 10.1108/14635771211242996.

Wang, H., Liu, X., Wang, N., Zhang, K., Wang, F., Zhang, S., Wang, R., Zheng, P. and Matsushita, M., 2020. Key Factors Influencing Public Awareness of Household Solid Waste Recycling in Urban Areas of China: A Case Study. Resources, Conservation and Recycling, 158, p.104813. doi: 10.1016/j.resconrec.2020.104813.

Wang, H. J. and Schmidt, P. 2002. One-step and Two-step Estimation of the Effects of Exogenous Variables on Technical Efficiency Levels. Journal of Productivity Analysis, 18(2), pp. 129-144. doi: 10.1023/A:1016565719882.

World Bank. 2019. Cleaning Up Indonesia's Urban Solid Waste. Available at: https://www.worldbank.org/en/ news/press-release/2019/12/05/cleaning-up-indonesias-urban-solid-waste (Accessed: 13 March 2021).

Zaman, A. U. 2016. A Comprehensive Study of the Environmental and Economic Benefits of Resource Recovery from Global Waste Management Systems. Journal of Cleaner Production. Elsevier Ltd, 124, pp. 41-50. doi: 10.1016/j.jclepro.2016.02.086. 